\title{
Should a Human Right Discourse be Applied to Labour Standards?
}

\author{
Morteza Shirzad
}

Sedighe Soltani

$\mathrm{PhD}$ candidate at Essex Univrsity.

Mshirz@essex.ac.uk

\begin{abstract}
Whether a rights discourse should be applied to labour standards, entails addressing two issues. Firstly, what are the philosophical grounds for labour rights and whether they are human rights at all? Even if they cannot be regarded as human rights, should they be applied strategically? While, there is no single comprehensive theory identified to provide sufficient grounding for all labour rights, this paper argues, firstly, that labour rights certainly lack characteristics of universal human rights since they are time-bound and place-bound. Secondly, while recognising the relatively large strategic turn to human rights discourse by labour scholars and labour organisations, this paper argues that this is not a universally applicable strategy and in fact in some contexts application of human rights discourse is counterproductive. The paper, thus, concludes that not only deploying human rights approaches when it comes to countries authoritarian contexts are not effective, but also it is highly likely to be counterproductive, since human rights discourse needs public rights awareness public and authoritarian contexts lack this awareness.
\end{abstract}

Keywords: Labour rights, Human Rights and Human Rights Discourse,

\section{Introduction}

Answering to the question whether a human right discourse should be applied to labour standards entails addressing three different but relevant questions. Firstly, whether Labour standards are rights, secondly whether it is then valid to conceptualize labour standards as human rights. Thirdly, whatever the response to the previous question might be, should the human rights discourse be applied in order to serve worthwhile ends?

The aim of this paper would accordingly be threefold. In the first part, two plausible philosophical foundations for labour rights would be addressed. It would be argued that labour standards are rights, but there is no single doctrine providing a comprehensive grounding for all labour rights. Subsequently, in the second part the question whether labour rights are human rights would be addressed arguing that while some labour rights are human rights, they certainly lack some characteristics of universal human rights since they are time-bound and place-bound. Finally, in light of the recent turn to the human rights discourse, the paper would then turn to this noticeable question whether the human rights discourse should be applied, arguing that developing a human rights discourse does not necessarily warrant worthwhile ends, and especially in some contexts it would be harmful for labour movements.

\section{Labour rights as trumps?}

To begin with, there are a number of theories for labour rights. ${ }^{1}$ Historically, as $\mathrm{H}$. Collins has identified there are two justifications. ${ }^{2}$ One of which mainly tries to address market failures and employment contracts through special regulations (i.e. efficiency-based justifications) and the second one provides grounding for consideration of fair dissemination of wealth known as social justification ${ }^{3}$. Yet, these justifications have not been without their critiques. The former have been challenged based on the way they could be implemented and its danger of dismantling special labour employment rules

\footnotetext{
1 Eg H Spector, 'Philosophical Foundation of Labour law' (2006) 33 Florida (2006), State University Law

2 Collins.H (2011) 'Theories of Rights As Justifications For Labour rights' in Davidov.G \& Lanhille.B(eds) Oxford University Press, P.137.

${ }^{3}$ Collins 'Theories' PP. 137-138. 
and the latter has been criticized based on lack of merits as well as possibility of using other less intrusive governmental measures like taxes for achieving social justice. ${ }^{1}$ These challenges share a common perspective: that these justifications are downplaying the role of obligatory employment standards and safeguards for ordered and organized labour. ${ }^{2}$ Hence, Collins suggests that if we can develop a strong theory of rights to elevate status of labour demands to the rights position then their values cannot be overridden and they will trump over any other sort of considerations, principals or policies. ${ }^{34} \mathrm{Of}$ different existing theories of rights providing ground for labour rights, two of the most plausible and palatable of them would be presented in the following.

One of the most famous theories of rights is Rawls' theory of justice. Drawing on his theory of veil of ignorance, Collins ${ }^{5}$ has tried to reformulate his theory in order to justify grounding for social and economic rights. He argues that behind the veil of ignorance no body knows their position in the market economy e.g. whether he or she would be employer or employee. However, a rational person, for example, identified, as a worker will have the basic income to support himself or herself and his or her family by taking a job behind this veil of ignorance. He therefore tries to pint out to "the potential of this method for providing foundation for a system of labour law." ${ }^{6} T$ The drawback of this theory, however, is that behind the veil of ignorance, nobody knows "his or her interest might be served or hampered by collective bargaining or whether his or her political belief might be favourable or hostile towards trade unions. Moreover, fundamental rights involving civil and political rights have been prioritized over other rights (e.g. through judicial decisions). Thus "fundamental rights would only serve the purpose of guaranteeing some aspects of labour law"7 i.e. they secure individual interests of workers rather than, for instance, the right to collective bargaining.

Another theory known as 'Dignity', which is to be addressed here, is related to values like 'dignity' and 'autonomy'. The idea of autonomy suggests having both negative and positive freedom within itself. ${ }^{8}$ Similarly, the idea of dignity could be interpreted in such a way that it carries the suggestion of decommodification of labour. ${ }^{9}$ The particular emphasis on individual dignity necessitates inclusion of both civil/ political rights as well as social/ economic rights into fundamental rights. Therefore, without social/ economic rights, civil liberties' value are considered as little and individuals dignity as not secured. ${ }^{10}$ Unlike the former theory mentioned above, this latter theory would meet the need for, for instance, collective bargaining to be considered as rights, since one important assumption is that "If civil liberties have to be protected as rights, necessary conditions for enjoyment of those rights, too, must be defended as rights."11

Evidently, these two sets of arguments, provides philosophical grounds for applying a right discourse to labour standards, go hand in hand like pieces of a puzzle to contribute to the body of what is regarded as the international labour law system. But should they be regarded as human rights, too?

\section{Labour rights as human rights?}

The best source and reference for addressing "internationally recognized worker rights", is the ILO declaration of 1998 in which the four sets of core labour standards (CLS) have primarily been focused on and prioritized ${ }^{12}$ as 'principals' rather than rights. ${ }^{13}$ Of several competing explanation offered regarding why there has been emphasis on calling them 'principal',

\footnotetext{
1 Collins 'Theories' P. 138.

2 Collins 'Theories' P. 139.

${ }^{3}$ Collins 'Theories' P. 139.

4 R Dworkin, 'Taking Rights Seriously' (1977) Harvard University Press Ch 12.

${ }^{5}$ Collins 'Theories' P. 146.

${ }^{6}$ Collins 'Theories' P. 150.

${ }^{7}$ Collins 'Theories' P. 151.

${ }^{8}$ C McCrudden, (2008) in id P. 151.

${ }^{9}$ Collins 'Theories' P. 151.

10 Collins 'Theories' P. 151.

11 Collins 'Theories' P. 153.

12 V A Leary 'The Paradox of Workers' Rights as Human Rights' in L A Compa and S F Diamond (eds) Human Rights, Labour Rights and International Trade, University of Pennsylvania Press, P. 28.

${ }^{13}$ Available at: www.ilo.org/ilolex/cgi-lex/convde.pl?C087 (15/12/2011)
} 
the most reasonable is that the relevant principals could not be referred as rights in so far as there were other states who had not ratified the specific International Labour Conventions regarding those four set of CLS. ${ }^{1}$

However, Philip Alston believes that "This explanation overlooks the fact that each of the relevant principals is recognized as human rights in the UDHR, in the ICESCR, which is binding upon 149 states and in the very body of other international legal standards." 2 Yet, what could soon be understood is that there are two conflicting point of views arguing whether labour rights are human rights or merely a set of principles.

One very straightforward and positivist way of putting labour rights as human rights is to say because rights such as the right to freedom of association ${ }^{3}$ has been incorporated in the UDHR 1948, therefore, this can provide a solid grounding for labour principals to be regarded as human rights. ${ }^{4} \mathrm{It}$ is on the same track that $\mathrm{V}$. Leary regards "the rights included in the basic human rights convention of the ILO, as "internationally recognized workers' rights"' 5 , looking at them from a different angle. She calls attention to the too narrow focus given to the both concept of workers' rights and human rights with the latter being narrowed to the exclusion of the social rights (including workers rights). ${ }^{6}$ Accordingly, while accusing labour advocates of failure to address worker rights as Human rights ${ }^{7}$, she states that perhaps the reason for regarding worker's rights as "merely claims" (largely in the United States) is the difficulty involved in protecting such rights. ${ }^{8}$ She concludes that this failure is because of disregard of "the context in which the ILO and international labour standards were originally created", particularly 'the link between workers' rights and peace'. 9 Therefore, the aforementioned nexus between the two, should be reemphasized and in this regard "human rights cannot exist without social justice" 10 and the right of workers, thus, should be seen as essential to the issue of human rights. In fact, she tries to remind the emphasis on the dignity of the individual, which have been expressed through rights in the Universal Declaration, to serve as a foundation for freedom, justice and peace. ${ }^{11}$ Hence, by the very fact that Civil and Political rights as well as Social and Economic rights have been incorporated in the Declaration, it could be understood that definition of human rights is big enough to answer to the "urges in favour of conditions of social justice" involving workers' rights. ${ }^{12}$

However, apart from the complex arguments as to universality of human rights and its roots in natural law, into which we are not here to delve, the aforementioned arguments as to calling labour rights as universal human rights have been challenged by some scholars like Kevin Kolben and Hugh Collins. Kolben draws a contrast between these two, asserting:

"In contrast to human rights, which are universal and possessed by all human beings by virtues of their humanity, labour rights can be defined as the set of rights that human beings posses by virtue of their status as workers." 13

Moreover, drawing on Waldron's argument, Collins ${ }^{14}$ identifies three more contrasts between universal human rights and labour rights in addition to what Kolben has presented. Firstly, labour rights unlike human rights do not present an urgent and compelling moral imperative, to be applicable universally. In this regard, it would suffice for one to compare the right not to be tortured with the right to a paid holiday. Secondly, unlike the respect for liberty and dignity, which are regarded as minimum standards below which no government should fall in operating, affordability matters in consideration of labour rights. What we regard as a fair pay or reasonable holiday is by large contingent upon the degree a country can afford.

\footnotetext{
1 Philip Alston, 'Labour Rights as Human Rights: The Unhappy State of the Art' in P. Alston (ed) Labour Rights as Human Rights, OUP, 2005, P. 3.

${ }^{2}$ Alston 'Labour Rights' P. 3.

${ }^{3}$ Article 20 UDHR

4 Tonia Novitz and Colin Fenwick, 'The Application of Human Rights Discourse to Labour Relations: Translation of Theory into Practice' in T. Novitz and C. Fenwick (eds) Human Rights at Work: Perspectives on Law and Regulation, Hart, 2010, P.3.

${ }^{5}$ Leary 'The Paradox' P. 28.

6 Leary 'The Paradox' P. 42.

${ }^{7}$ Leary 'The Paradox' P. 25.

${ }^{8}$ Leary 'The Paradox' P. 26.

${ }^{9}$ Leary 'The Paradox' P. 43.

10 Leary 'The Paradox' P. 43.

11 "Whereas recognition of the inherent dignity and of the equal and inalienable rights... is the foundation of freedom, justice and peace in the world..."

12 Collins 'Theories' P.142

${ }^{13}$ Kevin Kolben, 'Labour Rights as Human Rights?' (2010) 50 Virginia Journal of International Law P.453.

14 Collins 'Theories' P. 142
} 
Lastly, whereas human rights are conceived as everlasting fundamental demands, labour rights evolve according to the way a government produce its wealth and are subject to "progressive implementation"1. In other words, they are very much time-bound and place-bound.

The latter arguments seem to be rational for two reasons. In the first place, labour rights cannot be regarded as universally absolute in the sense we use these characteristics for human rights mainly because they are very much place-bound and time-bound (though important and vital) and, furthermore, affordability of states matters when it comes to defending labour rights.

Additionally, the mere existing of social rights in black and white on the Declaration does not lend itself to be a potent reason for considering labour rights as human rights. Especially at least historically, it is identifiable that many labour standards were reformulated to the language of rights primarily as a response to atrocities committed by oppressive states rather than for values like dignity or being primarily fundamental absolutes.

\section{3- Strategic turn to human rights discourse}

Having mentioned that at the philosophical level, arguments providing ground for labour rights to be regarded as human rights are not potent (at least not for all of them), this question remains to be responded that whether human rights' language could be or should be invoked and applied even if labour rights cannot be recognized as human rights.

K. Kolben ${ }^{2}$ has identified that there has been a large strategic turn to human rights discourse by labour scholars and labour organizations. He believes that human rights discourse has such hegemonic status that labour activists would like to take its advantage and "relative effectiveness". In fact, he points out to two important points: firstly, it is the value of the human rights and rights as trumps and secondly, there is then a practical side i.e. that is the relative effectiveness of some human rights' advocacy strategy, what he calls the hegemonic status of the human right's discourse. Many activists, he believes, use human rights discourse to gain public support for labour rights campaigns as a much more powerful way of attacking and criticizing multinational enterprises. ${ }^{3}$

Moreover, In line with these campaigners and in light of the fact that using human rights strategically has served labour activists very well in many issues and lawyers have been successful and found it conducive to advance certain claims by invoking the rights contained in Bills of Rights, $\mathrm{H}$. Collin believes that:

"Any weakness of philosophical underpinnings for labour rights should not deter lawyers from adopting these legal strategies in order to serve worthwhile ends."4

However, Kolben asserts that even though the strategy adopted by labour campaigns and activists have been highly effective in pushing the states for achieving certain goals, yet it could be less efficient and in fact incapacitating for labour rights actors that chiefly functions in the private economic sectors. ${ }^{5} \mathrm{He}$ goes further by saying that legalism, elitism; individualist and philanthropic features of human rights approaches do not necessarily benefit labour movement. ${ }^{6} \mathrm{He}$ explains that:

"The international human rights movement is not fundamentally committed to examining and questioning fundamental economic relationships in society, nor it is committed to direct action as a method- or workplace as a goal- to same extent as the labour movement."

Furthermore, in response to what Collins has prescribed as a valid approach to invoke human rights' hegemonic status, this paper would argue that deploying human rights approaches when it comes to countries like Iran or any other

\footnotetext{
1 J. Fudge, 'The New Discourse of Labour Rights: From Social to Fundamental Rights?' (2007), Comparative Labour Law and Policy Journal, 29, P.36.

2 Kolben 'Labour Rights' P. 451.

${ }^{3}$ Kolben 'Labour Rights' P. 453.

${ }^{4}$ Kolben 'Labour Rights' P. 453.

${ }^{5}$ Kolben 'Labour Rights' P. 484.

${ }^{6}$ Kolben 'Labour Rights' P.453

${ }^{7}$ Kolben 'Labour Rights' P. 453.
} 
authoritarian contexts not only are not effective, it is in fact counterproductive since public supports could be gained by labour rights campaigns only where there is a public rights awareness. For instance, in Iran military service is compulsory for every man after being 18 years old for the period of up to two years. Ironically, during the last 36 years many Iranian men, in the name of serving to their country has been employed to work under such titles as "soldier teacher" or "tasked soldier" to do basically anything for a very small amount of money or non. ${ }^{1}$ This is regarded as forced labour either by the ILO or the UDHR. The point that here is being made is that in absence of minimum right awareness; there is not such a thing as human rights hegemonic status. On the other hand, eastern authoritarian governments, perhaps with the contribution of some anthropologists, have achieved a relative success in making popular ${ }^{2}$ the claim that human rights ideas are relative, Western ${ }^{3}$, and not applicable in, for example, Islamic societies. Therefore, in absence of hegemonic status of human rights discourse and public rights awareness implementation of human rights discourse appears to be debilitating for labour activists. Hence, what is to be avoided, is in fact, the so called strategic implementation of human rights language when it comes to those countries in which culture and power are proxy ${ }^{4}$ in the way of achieving worthwhile ends. This is where we come to this conclusion that it is the context that, contingent on the time and place, determines whether applying of the human right discourse is conducive.

In conclusion, whether a human right discourse should be applied to labour standards entails addressing firstly, capability of these standard to be regarded as rights or human rights, secondly, capability of the context in which these standards/rights are going to be promoted. In the first part, two famous theory of labour rights was examined in this paper namely, the theory adopted by Collins based on Rawls theory of justice and the Dignity theory. While the former theory provided grounding for more individualistic set of workers' rights, the latter gave rise to the rights like the right to collective bargaining. As a result, it was concluded that there is no single comprehensive theory identified to provide sufficient grounding for all labour rights. Thus, each of these theories contributes to constitute part of this body of international labour law system. In the second part, the question whether labour rights could be regarded as human rights has been addressed arguing that labour rights because of their very nature- that are time-bound and place-bound- they do not have capability of being called universal human rights. Finally, in the last part this recent turn to human rights has been analyzed arguing that using the language of human rights in two respects could be debilitating for labour movements in some contexts. Firstly, with respect to what Kolben has identified as conflicting characteristics between human rights and labour rights on the one hand and human rights movements and labour movements on the other, they do not necessarily benefit from each other. Secondly, with respect to those countries, mainly eastern and Islamic countries, that culture and power is considered as a proxy in the way of human rights promotion, strategic employment of human rights language would certainly not be recommended since the hegemonic status of human rights, does not apply in a country such as Iran where citizens are not able to scrutinize the actions of their state by reference to human rights discourse. In short, care should be taken as regards strategic usage of human rights discourse as the contexts plays an important on success and failure of such approaches.

\section{References}

[1] Alston, P. (2005). Labour rights as human rights: The Unhappy state of the art' in P. Alston (Eds.), Labour Rights as Human Rights, Oxford: OUP.

[2] Collins, H. (2011) Theories of rights as justifications for Labour Law' in Davidov, G and Langille, B (Eds.), The Idea of Labour Law (pp. 137-155). Oxford, UK: Oxford University Press.

[3] Engle, K. (2000). Culture and Human Rights: The Asian Values Debate in Context. New York University Journal of International Law and Politics, 32, 291-333

[4] Freedom of Association and Protection of the Right to Organise Convention (2015, July 3), Retrieved from www.ilo.org/ilolex/cgi-lex/convde.pl?C087

\footnotetext{
${ }^{1}$ Mesdaghi. I (2010) 'The ILO at a glance, Violation of Fundamental rights of workers in Iran (1st ed) ALFABET MAXIMA, P. 23.

${ }^{2}$ It is obvious that a popular argument does not necessarily possess a valid and potent philosophical ground.

${ }^{3}$ Karen Engle, 'Culture and Human Rights: The Asian Values Debate in Context' (2000) 32 New York University Journal of International Law and Politics P. 329.

${ }^{4}$ Engle, 'Culture' P.329.
} 
[5] Fudge, J. (2007). The New Discourse of Labor Rights: From Social to Fundamental Rights? Comparative Labor Law and Policy Journal, 29, 29-66.

[6] Hepple, B (2005). 'Labour Laws and Global Trade, London, England: Hart.

[7] Information System on International Labour Standards (2015, July 3), Retrieved from http://www.ilo.org/ilolex/english/convdisp1.htm

[8] Kolben, k. (2010). Labor Rights as Human Rights? Virginia Journal of International Law, 50, 449-484.

[9] Leary, V.A. (1996). The paradox of workers' rights as human rights' in Compa , L.A \& Diamond, S.F. (Eds.), Human Rights, Labour Rights and International Trade, University of Pennsylvania Press, 22-47.

[10] Novitz, T \& Fenwick, C. (2010). The application of human rights discourse to labour relations: Translation of Theory into Practice' in Novitz, T and Fenwick, C (Eds.), Human Rights at Work: Perspectives on Law and Regulation, London: Hart. 